\title{
The Characteristics of "the Five Chapters on the Various Gods and Goddesses" in the Suvarnaprabhāsa
}

\author{
SuzuKI Takayasu
}

\section{The Aim of This Paper: A Continuous Verification of the Hypothesis}

As has been discussed in the previous studies, ${ }^{1)}$ the Suvarnaprabhāsa (Sütra of Golden Light; Suv $),{ }^{2)}$ one of the Mahāyāna Buddhist scriptures which has collected and demonstrated various doctrines and rites of both mundane and supermundane levels, and has had wide influence over the way of thinking and living of Asians, seems to have been paid rather scant attention by the modern scholarly world partly because the intention of the compilers of the $S u v$ has long remained unknown. In this relation, supported by some archeological results, ${ }^{3)}$ the present author, focusing attention on the complicated structure of the $S u v$ and in particular on the description in the Caturmahäräja-parivarta, ${ }^{4)}$ has already proposed the following hypothesis on the intentions of the compilers of the Suv:

〈The Hypothesis〉 Owing to the account of the Suv which has, through the several stages of its formation, collected and demonstrated the various kinds of doctrines and rites of both mundane and supermundane levels expounded previously in the treatises either of Mahāyāna, of non-Mahāyāna, or of non-Buddhism (i.e., of Hinduism), the compilers and the proponents of the $S u v$ became more able to lead their daily religious lives, including their practice of various rites and their attainment of various religious merits, in accordance with "the teaching of the $S u v$," that is, "the teaching of [Mahāyāna] Buddhism." We can therefore interpret the features appearing in the $S u v$ not as a token of "the assimilation of Buddhism into Hinduism" or "the depravity of Buddhism," but as an attempt of Buddhists to survive in the Indian religious world by emphasizing the value, the usefulness, and the completeness of [Mahāyāna] Buddhism under the circumstances where Hinduism had become more and more dominant over Buddhism (during and after the Gupta period). Moreover, if one of the intentions of the compilers of the Suv lies in this attempt by collecting as many doctrines and rites as possible, however of mundane or supermundane levels, or of Buddhism or non-Buddhism they might be, from the stage of the formation of the $S u v_{C I}$ to that of the $S u v_{C 3}$ consistently, we can suppose that the intention of the compilers has remained unchanged all through the stages of the formation of the $S u v$. Furthermore, it may turn out that the $S w$ is not "a mere miscellaneous med- 
ley of doctrines and rites," but a collection of them which is intrinsic to the value of the $S u v$.

This paper continues to verify this hypothesis by examining the characteristics of "the Five Chapters on the Various Gods and Goddesses." 5) Since the examination of four chapters among the five has been made in a series of previous studies (see Suzuki [2004, 2005, 2006, and 2007]), we will begin with a brief survey of the Samjñ̄aya-parivarta (Chapter on the great Yakșa general Samjñ̃aya; Chapter $19^{6)}$ of the $S u v$ ), which is the fifth and final chapter in "the Five Chapters on the Various Gods and Goddesses."

\section{A Brief Survey of the Samjñ̄āya-parivarta (Chapter on the great Yakșa general Saṃjñāya; Chapter 19)}

The Samjñ̄aya-parivarta can be divided into three sections (from $\S 1$ to $\S 3$ ) as follows:

$\S$ 1: The great general of the Yakṣas called Samjūāya (僧慎爾耶薬叉大将), together with the twenty-eight great Yakșa generals, vows to the Lord Sākyamuni that he shall approach any place wherever the $S u v$ goes forth, and with invisible body give protection, help, peace, and welfare to the clergyperson who preaches the $S u v$. He shall also give protection, help, peace and welfare to all those laypersons whoever should hear even one four-verse stanza or even one verse from the $S u v$, should hear even the name of the $S u v$ and accept it. Their dwelling places shall be also given protection, help, peace and welfare by him.

Next, the great Yakșa general Samjñāya gives the following explanation of why he has been named Samjuñāya.

By him, all things are fully known, fully examined, fully comprehended, fully surveyed, and fully perceived. All things are apparent to him. The splendor, the extent, the quantity, and the sphere of his knowledge are inconceivable. For this reason, he has been given the name Samjñāya. (Summarized; $S u v_{S}$ 129.13-130.8. See Emmerick [1996: 58-59].)

Then the great Yakṣa general Samjñ̄āya makes a vow in the presence of the Lord Śākyamuni to offer both mundane and supermundane merits to those who preach or hear the $S u v$, a few examples of which are to have happy senses, to be full of joy, or to experience inconceivable divine and human pleasures (mundane merits), and to awaken to supreme and perfect enlightenment in future time (supermundane merit). The preachers of the Suv shall be granted eloquence, great energy, strength, prowess, and the inconceivable splendor of knowledge.

With the end of his vow, the first Chinese version $S u v_{C I}$ rendered by Dharmakșema (曇 無䜟) in the 5th century (412-421), the second Chinese version $S u v_{C 2}$ combined by Băo-guì 

and Goddesses" in the Suvarnaprabhāsa (T. SuzukI)

（寶貴） in 597, the Sanskrit text $S u v_{s}$, and the smaller Tibetan version $S u v_{T 1}$ conclude this Chapter 19.

$\S 2$ : This $\S 2$ and the next $\S 3$ only exist in the larger Tibetan version $S u v_{T 2}$ and the third Chinese version $S u v_{C 3}$ rendered by Yì-jìng (義淨) in the year 703 .

The great Yakșa general Samjñ̃āya states that he holds a spell (gzuñs sñags, *dhāranī; snags, *mantra; rig snags, ${ }^{*}$ vidy $\left.\bar{a}\right)$ which can bring about the welfare and blessing to all sentient beings, and he gives instructions how to employ it involving drawing the image ( $g z u g s$, ${ }^{*}$ pratima $\bar{a}$ ) of Samjñ̃āya, making an altar (dkyil 'khor, *mandala), and practicing burntoffering (sbyin sreg, *homa). The holders of this spell can be blessed with the supply of human blessing such as foods, cloths, flowers, fruits, fortunes, and jewels. According to their wishes, they are also granted sons, daughters, servants, gold, silver, and other ornaments. In the presence of those who have employed it one hundred and eight times, the great Yakșa general Samjñ̃aya shall make his appearance (i.e. become visible) and grant whatever wishes of them such as being replete with gold, silver, and acquiring six supernatural powers. Moreover all sentient beings shall be able to attain the deliverance (rnam par grol ba, *vimokșa, vimukti) from every affliction (ñon mons pa thams cad, ${ }^{*}$ sarvakleśa).

$\S 3$ : The Lord offers congratulations to the great Yakșa general Samjjñãya who has instructed how to employ the spell in order to benefit all sentient beings and protect the $S u v$, and prophesies that he will obtain immeasurable merits.

The structure of Chapter 19 can be tabled as follows:

Table 1. The structure of the Samjñaya-parivarta (Chapter 19)

\begin{tabular}{|c|c|c|c|c|c|c|}
\hline & $\operatorname{Suv}_{C 1}$ & $\operatorname{Suv}_{S}$ & $\operatorname{Suv}_{T 1}$ & $\operatorname{Suv}_{C 2}\left(=S u v_{C I}\right)$ & $\operatorname{Suv}_{T 2}$ & $\operatorname{Suv}_{C 3}$ \\
\hline$\S 1$ & $346 \mathrm{~b} 16-\mathrm{c} 18$ & $128.4-131.8$ & $100.1-102.21$ & $389 \mathrm{~b} 22-\mathrm{c} 22$ & $=S u v_{T I}$ & $441 \mathrm{a} 27-\mathrm{b} 29$ \\
\hline$\S 2$ & - & - & - & - & $306.2-307.17$ & $441 \mathrm{c} 1-442 \mathrm{a} 10$ \\
\hline$\S 3$ & - & - & - & - & $307.18-24$ & $442 \mathrm{a} 11-13$ \\
\hline
\end{tabular}

We can see from Table 1 that the content of the Samjñayya-parivarta was enlarged through the two stages of formation.

Chapter 19: $S u v_{C I}\left(=S u v_{C 2}\right), S u v_{S}, S u v_{T 1}$ (the first stage) $\rightarrow S u v_{T 2}, S u v_{C 3}$ (the second and

last stage) 
The Characteristics of "the Five Chapters on the Various Gods and Goddesses" in the Suvarnaprabhāsa (T. SUZuKI)

\section{The Characteristics of "the Five Chapters on the Various Gods and Goddesses"}

What has to be noted first is that all the Gods and Goddesses in "the Five Chapters" have been beforehand listed twice in the Caturmahäraja-parivarta which is the first chapter of them all.

[Caturmahāräjas said thus to the Lord:] "[By the hearing of the Suv] there will arise umbrellas of vines of various perfumes and fragrances, arriving at that instant, moment, second, in the sky above the several palaces, dear Lord, of Sarasvatī, the great goddess, of Drụhā, the great goddess, of Śrī, the great goddess, of Samjñaya, the great general of the Yakșas, and of the twenty-eight great generals of the Yakșas, ..." ( $S u v_{S}$ 84.13-85.7. See Emmerick [1996: 34].)

[Caturmahārājas spoke thus to the Lord:] "Sarasvatī, the great goddess, Śrī, the great goddess, Drụhā, the great goddess, Samjñãaya, the great general of the Yakșas, and the twenty-eight great generals of the Yakșas, ..., with invisible bodies [will approach for the hearing of the Suv]." (Suv 91.15-92.4. See Emmerick [1996: 38].)

Having examined them, what is more, we find that "the Five Chapters" and the Gods and Goddesses appearing in them have the following seven remarkable characteristics (from $[\mathrm{C}-1]$ to $[\mathrm{C}-7]$ ) in common:

[C-1] All of the Gods and Goddesses in "the Five Chapters," that is, Caturmahārājas, Sarasvatî, Srī, the Earth-goddess, and Yakșas, are very popular deities in Indian tradition.

[C-2] When the $S u v$ is expounded, these deities become powerful and vigorous enough to benefit and protect the sentient beings and their dwellings, villages, cities, forest-retreats, palaces, countries, and regions. ${ }^{7)}$ Therefore the necessity for honoring the $S u v$ and its preachers is much emphasized. ${ }^{8)}$

[C-3] The acts of benefit and protection by these deities are carried out with invisible bodies. ${ }^{9)}$

[C-4] The merits granted by these deities are of both mundane and supermundane levels, that is, not only the ones peculiar to Buddhism but also those merits which are mundane and popular in India.

[C-5] Different kinds of hearers or proponents are expected in every chapter:

Caturmahäräja-parivarta: The kings or the rulers, the greater part of whom might have been non-Buddhists during and after the Gupta period. (See Sanderson [2004a, 2004b, and 2005] and Suzuki [2005: 20-23].)

Sarasvati-parivarta: Those who are concerned with the ability of speech, extensive knowledge of all the textbooks (e.g. Brahmins), and success in the performance of various arts, and those who exercise the act of ritual bathing, that is, the greatest part of Indian people. ${ }^{10)}$ Srï-parivarta: Those who are interested in increasing their fortune or wealth (e.g. householders or merchants. See Suzuki [2006: 43-45]). 

and Goddesses" in the Suvarnaprabhāsa (T. SUzUKI)

Drdha-parivarta: Those who were engaged in agriculture, that is, the farmers in India, the greater part of whom might have not been Buddhists at that time. (See Suzuki [2007: 65-70].) Samjiñaya-parivarta: Those who have belief in Yakṣas which had been widely spread and accepted in Indian culture. ${ }^{11)}$

[C-6] Rites for both mundane and supermundane merits, which involve employing magic spells (mantra, dhāranī, or vidyā), are taught in the developed stages of formation. ${ }^{12}$ )

[C-7] The characteristics listed from $[\mathrm{C}-1]$ to $[\mathrm{C}-5]$ remain unchanged all through their variegated process of compilation. (See Suzuki [2005: 25-26].)

Taking these two factors (having the names of the deities listed in advance and sharing the seven characteristics among the chapters) into consideration, we can say in the first place that "the Five Chapters" have been compiled under a unified editorial policy.

Secondly, [C-5] indicates that the expected hearers or proponents of "the Five Chapters" can include people of the various classes in Indian society. Moreover the exercise of ritual bathing and the belief in Yakșas had widely spread beyond the classes or their religions in a narrow sense, and it may not be too much to say that having interest in the acquisition of and the increase in wealth is more or less one of the intrinsic tendencies of the ordinary people. Therefore it seems reasonable to suppose that the compilers of the $S u v$, in preparing "the Five Chapters," might have intended to attract various kinds of people whether they were Buddhists or not.

Thirdly, the account that draws our attention most is that all those deities who accomplish with invisible bodies the act of benefit and protection to the people ([C-3]) have been encouraged by the nectar juice of the $S u v$, or to put it more directly, by the "grace" of the Buddhist monks (or nuns) who preach the $\mathrm{Suv}$ ([C-2]). On this assumption, it necessarily follows that the peace and security of a region, the stable sovereignty, the proper movement of the heavenly bodies (in the Caturmahäräja-parivarta), the eloquence in speech, the skillfulness in arts, the merits attained by the act of ritual bathing (in the Sarasvati-parivarta), the acquisition of and the increase in wealth (in the Srí-parivarta), the increase in the moisture and the savor of the earth, the health and the longevity of the people who take the various tasty fruits and crops that have grown well in the strong earth (in the Drdha-parivarta), and that the much greater merits of both mundane and supermundane levels can be attained by the belief in Caturmahārājas, in Sarasvatīi, in Śrī, in the Earth-goddess, and in Yakșas than by the traditional belief before the Suv (all through "the Five Chapters"), all these "merits" have already been, whether people may recognize the "grounds" or not, brought about in 
secret by the invisible deities encouraged by the Buddhist monks who had been "well honored." If any misfortune or inconvenience occurs, it is to be attributed for the same reason to the lack or the insufficiency of honoring the $S u v$ and its preachers. Therefore those who wish themselves well and to avoid any misfortune or inconvenience (see n.8), must pay homage to and make offerings to the Buddhist monks who hold and preach the Suv. ${ }^{13)}$ All these factors considered, it is highly probable that the unified editorial policy under which "the Five Chapters" have been compiled should be associated with the intentions described in 〈the Hypothesis〉.

Finally, we must discuss the reason why "the Five Chapters" conclude with the Samjinaya-parivarta. Let us remember here the description in the Caturmahârāja-parivarta cited in n.4. This description insists upon the superiority of Buddhism over Hinduism on the grounds of the usefulness and the completeness of the $S u v$ which comprehends the various kinds of doctrines and rites of both mundane and supermundane levels, and of both Buddhism and non-Buddhism. In addition, the expected hearers of this chapter must be those who belong to royal families. Having associated with 〈the Hypothesis〉, this Caturmahäraja-parivarta is supposed to be compiled to induce the people belonging to the class of kings to become the proponents of the $S u v$ in order to obtain their aid for the sake of accomplishing the transmission of the Law and religious practice for the supreme enlightenment.

In the Samjiñaya-parivarta, on the other hand, the main character is a Yakșa general who has been given name Samjñāya. As illustrated in Chapter 2 of this paper, "by him, all things are fully known, fully examined, fully comprehended, fully surveyed, and fully perceived. All things are apparent to him." He is also described as the head of the twentyeight great Yakșa generals $\left(S u v_{S} 128.4-5\right.$, etc.). These twenty-eight great Yakșa generals are furthermore explained in the Caturmahārāja-parivarta as the chief retinues of Caturmahārājas $\left(S u v_{S} 66.1-2\right.$, etc. $)$.

To take all these factors into account, it can be said that all things Samjñãya fully knows must include the various kinds of doctrines and rites of both mundane and supermundane levels, and of both Buddhism and non-Buddhism, and that the existence or the faculty of the Yakṣa general Saṃjñāya, who knows "all things," must be one of the main grounds that enables Caturmahārājas to emphasize the completeness of the $S u v$ to the members of royal families. Involving three intermediate chapters, that is, the Sarasvatī-parivarta, the Śrī- 
parivarta, and the Drdhā-parivarta, by which the compilers of the $S u v$ attempt to attract the various kinds of people who can be governed by the kings, "the Five Chapters" begin with the Caturmahärāja-parivarta and conclude with the Samjñāya-parivarta, the former of which has been compiled for converting royal families to Buddhism, and the latter of which can reinforce the discourse of the former.

From the examination of "the Five Chapters" we can recognize the deep consideration of the compilers of the $S u v$ how to induce the kings to become their proponents. It would be untrue to presume the expressions of this consideration confined only within "the Five Chapters." After "the Five Chapters," in fact, follows directly the Devendrasamayaparivarta (Chapter on Instruction Concerning Divine Kings; Chapter 20 of the Suv), which instructs what a king should be who has to rule various people and exercise his kingship in order to realize the welfare of the people.

Buddhism had once stood foremost in the religious world of India under the patronage of the great kings such as King Aśoka of the Maurya Empire or King Kanișa of the Kushan Empire. However during and after the Gupta period when the Suv was compiled, Buddhism has been already lost its dominant position to Hinduism. Under such circumstances the compilers of the $S u v$, by obtaining various kinds of aid of the kings as well as of their people, must have attempted to survive in the religious world for the sake of accomplishing the duties of the Buddhist clergy.

\section{Conclusion}

We can say, from what has been discussed above, that the validity of 〈the Hypothesis > has been even more strengthened. "The Five Chapters" begin with the Caturmahāräjaparivarta which emphasizes the superiority of Buddhism over Hinduism and attempts to convert the people of the class of kings to Buddhism. After the successive attempts in the following three chapters to attract the people of the various classes who are ruled by the kings, "the Five Chapters" conclude with the Samjñāya-parivarta in which a Yakșa general who is the head of the chief retinues of Caturmahāājas and knows all things whether of mundane or supermundane levels, and whether of Buddhism or non-Buddhism, plays an important role to reinforce the discourse of the Caturmahäräja-parivarta.

From the examination of "the Five Chapters" we can recognize the deep consideration of the compilers of the Suv toward the members of royal families. From this consideration 
The Characteristics of "the Five Chapters on the Various Gods and Goddesses" in the Suvarnaprabhāsa (T. SuzuKI)

they have successively compiled the Devendrasamaya-parivarta which follows directly after "the Five Chapters."

1) Suzuki, T. [1996] The Mahāmeghasūtra as an Origin of an Interpolated Part of the Present Suvarnaprabhāsa, Journal of Indian and Buddhist Studies 89 (45-1), Tokyo, pp. 28-30; Suzuki, T. [2003] Stüpa Worship and Dharma Evaluation in the Suvarnaprabhāsa, Journal of Indian and Buddhist Studies 102 (51-2), Tokyo, pp. 32-36; Suzuki, T. [2004] Rites and Buddhism: A Perspective from the Sarasvati-parivarta in the Suvarnaprabhāsa, Journal of Indian and Buddhist Studies 104 (52-2), Tokyo, pp. 12-17; Suzuki, T. [2005] The Unchanged Intention of the Compilers of the Suvarnaprabhāsa: An Examination through the Verification of the Hypothesis on "the Independence of [Mahāyāna] Buddhism," Journal of Indian and Buddhist Studies 106 (53-2), Tokyo, pp. 20-26; Suzuki, T. [2006] The Primary Introduction of the Rites for Good Fortune into the Suvarnaprabāsa Described in the Śrī-parivarta, Journal of Indian and Buddhist Studies 109 (54-3), Tokyo, 2006, pp. 42-50; Suzuki, T. [2007] An Intention of the Compilers of the Suvarnaprabhāsa Expressed and Intimated in the Drdhā-parivarta, Journal of Indian and Buddhist Studies 112 (55-3), pp. 64-72; and Suzuki [1998a, 1998c, 1999, 2005a and $2005 \mathrm{~b}]$ in Japanese.

2) 〈Texts and Abbreviations〉

Suv Suvarnaprabhāsa or Suvarṇa[-pra-] bhāsottamasūtrendrarāja.

$S u v_{C l}$ 『金光明經』四卷, 曇無識譯. T. No. 663 .

Suv $v_{S} \quad$ Suvarnabhāsottamasūtra, ed. J. Nobel, Leipzig, 1937.

$S u v_{T 1} \quad$ 'phags pa gSer 'od dam pa mdo sde'i dbañ po'i rgyal po źes bya ba theg pa chen po'i mdo, ārya-Suvarnaprabhāsottamasūtrendrarāja-nāma-mahāyāna-sūtra, tr. unknown. P No. 176.

$S u v_{C 2}$ 『合部金光明經』八卷, 寶貴合糅. T. No. 664 .

$S u v_{T 2}$ 'phags pagSer 'od dam pa mdo sde'i dbañ po'i rgyal po źes bya ba theg pa chen po 'i mdo, ārya-Suvarnaprabhāsottamasūtrendrarāja-nāma-mahāyāna-sūtra, tr. Jinamitra, Śîlendrabodhi and Ye śes sde. P No. 175.

$S u v_{C 3}$ 『金光明最勝王經』十卷, 義淨譯. T. No. 665 .

$S_{u} v_{T} \quad$ Suvarṇaprabhāsottamasūtra, ed. J. Nobel, Leiden, 1944.

(T. Taisho Tripițaka; P Peking Kanjur)

The other notes had to be omitted for lack of space.

(This research was partly supported by Japan Society for the Promotion of Science, Grant-inAid for Scientific Research (C), 19520053, 2007.)

〈Key words〉金光明最勝王経僧慎爾耶薬叉大将品, 金光明経散脂鬼神品, 金光明経の編纂意図,【大乗〕仏教の生き残り策としての金光明経, インド〔大乗]仏教の実像理解.

(Professor, Yamaguchi Prefectural University, D.Litt.) 